\title{
KEKUATAN PEMBUKTIAN \\ REKAM MEDIS KONVENSIONAL DAN ELEKTRONIK
}

(Studi Perbandingan Hukum Terhadap Undang-Undang Nomor 29 Tahun 2004 Tentang Praktik Kedokteran, Undang-Undang Nomor 44 Tahun 2009 Tentang Rumah Sakit, Kitab UndangUndang Hukum Acara Pidana Nomor 8 Tahun 1981, Kitab Undang-Undang Hukum Perdata Dan Permenkes Nomor 269/MENKES/PER/III/2008 Tentang Rekam Medis)

\author{
Nabil Atta Samandari, Wila Chandrawila S dan Agus H. Rahim \\ kingbi@ymail.com \\ Magister Hukum Kesehatan \\ Universitas Katolik Soegijapranata Semarang
}

\begin{abstract}
ABSTRAK
Rekam medis adalah berkas berisi catatan tentang pasien, yang dibuat berdasarkan kronologis waktu. Terdapat dua jenis rekam medis dan secara umum telah diatur dalam Permenkes Nomor 269/MENKES/PER/III/2008 tentang Rekam Medis. Salah satu manfaat dari rekam medis adalah sebagai alat bukti dalam proses penegakan hukum.Timbul pertanyaan: apakah ada perbedaan kekuatan pembuktian diantara kedua rekam medis ini? Apakah penyebab perbedaan tersebut?
\end{abstract}

Penelitian ini menggunakan Metode Penelitian Deskriptif, Studi Komparatif, dengan pendekatan Metode Penelitian Yuridis Normatif. Data yang dikumpulkan adalah data kualitatif. Hal ini dilakukan untuk memperoleh gambaran tentang perbedaan dan penyebab perbedaan kekuatan hukum pembuktian dari kedua jenis rekam medis.

Perbedaan kekuatan pembuktian terletak pada tidak dipenuhinya syarat rekam medis elektronik sebagai alat bukti tertulis/surat, sesuai dengan KUHPer Buku 4, tentang Pembuktian Dan Daluarsa, Bab Kedua tentang Pembuktian Dengan Tulisan dan KUHAP Pasal 184 ayat (1) huruf c dan d, serta Pasal-Pasal 187 dan 188 ayat (2) huruf b. Artinya rekam medis konvensional dapat digunakan sebagai alat bukti asli tertulis, sedangkan rekam medis elektronik tidak.

Penyebab dari perbedaan itu karena baik KUHPer maupun KUHAP, kekuatan pembuktian tulisan, hanya dalam bentuk tulisan, berupa surat asli dan/atau akta otentik.

Kata Kunci : Rekam Medis, Kekuatan Pembuktian, Alat Bukti Tertulis, Rekam Medis Konvensional, Rekam Medis Elektronik. 


\section{PENDAHULUAN}

Kesehatan termasuk bagian dari kebutuhan dasar manusia. Karena tanpa kesehatan sulit bagi seseorang untuk melakukan aktifitas sehari-hari dan memenuhi kebutuhan-kebutuhan lainnya dalam hidup ini. Kesehatan sendiri tidak terlepas dari upaya pelayanan kesehatan dan sarana pelayanan kesehatan.

Upaya pelayanan kesehatan dapat diartikan sebagai suatu rangkaian kegiatan yang dilakukan secara terpadu, terintegrasi dan berkesinambungan, yang bertujuan antara lain untuk memelihara dan meningkatkan derajat kesehatan masyarakat. Hal ini dapat dilaksanakan dalam bentuk pencegahan penyakit, peningkatan kesehatan, pengobatan penyakit, dan pemulihan kesehatan (preventif, promotif, kuratif dan rehabilitatif). Untuk mendukung upaya kesehatan tersebut, diperlukan tersedianya sumber daya kesehatan, di mana dua komponen utamanya adalah para tenaga kesehatan (termasuk tapi tidak terbatas pada dokter dan dokter gigi) dan sarana pelayanan kesehatan.

Rumah sakit merupakan salah satu bentuk dari sarana pelayanan kesehatan tersebut. Didalamnya, para tenaga kesehatan melaksanakan pelayanan kesehatan. Dalam memberikan pelayanan kesehatan tersebut, tenaga kesehatan mempunyai kewajiban untuk memberikan pelayanan yang berkualitas (bermutu), optimal dan berkesinambungan. Salah satu cara untuk memastikan terwujudnya kewajiban tersebut adalah melalui pelaksanaan kewajiban lainnya yaitu melakukan pencatatan dan pendokumentasian di dalam berkas rekam medis secara tepat, akurat dan bertanggung jawab oleh para tenaga kesehatan tersebut.

Rekam medis bukanlah sekedar catatan dan pendokumentasian semata. Rekam medis merupakan suatu berkas data yang berisikan identitas pasien, segala tindakan yang dilakukan (sejak awal) terhadap pasien dalam rangka pemberian pelayanan kesehatan. Pencatatan dan pendokumentasian tersebut harus tertera secara kronologis, sistematis dan akurat, sehingga akan memberikan gambaran informasi perjalanan penyakit seseorang, tindakan-tindakan investigasi yang telah dilakukan terhadapnya, informasi rencana penatalaksanaan, catatan observasi klinis dan hasil pengobatan, persetujuan/penolakan suatu tindakan, ringkasan pulang (discharge summary), serta nama dan tanda tangan tenaga kesehatan yang memberikan pelayanan kesehatan tersebut.

Hal ini semua harus juga sejalan dengan prinsip pelayanan berkesinambungan (continuity of care). Dengan demikian, rekam medis yang baik, akan mencerminkan suatu praktik kedokteran yang baik dan bertanggung jawab serta menunjukkan pula bahwa tenaga kesehatan memiliki kinerja dan kedisipilinan yang baik.

Mengenai rekam medis itu sendiri sudah diatur dalam beberapa Undang-Undang, yaitu Undang-Undang Nomor 29 tahun 2004 tentang Praktik Kedokteran, Undang-Undang Nomor 44 Tahun 2009 tentang Rumah Sakit serta Permenkes Nomor 269/MENKES/PER/III/2008 tentang Rekam Medis, sebagai pelaksanaan Pasal 47 ayat (3) Undang-Undang Nomor 29 tahun 2004 tentang Praktik Kedokteran. Di dalam kedua peraturan yang disebutkan di atas itu, disebutkan mengenai kewajiban seorang dokter dan dokter gigi untuk membuat rekam medis secara lengkap, jelas dan akurat. Bahkan dalam Permenkes tersebut juga disebutkan mengenai pentingnya membubuhkan identitas nama, waktu dan tanda tangan.

Kemudian di dalam Undang-Undang Nomor 44 Tahun 2009 tentang Rumah Sakit juga disebutkan mengenai rekam medis. Di dalam Undang-Undang ini, rumah sakit diwajibkan menyelenggarakan rekam medis, sebagai suatu bentuk pencerminan pelayanan kesehatan yang bertanggung jawab. 
Rekam medis sebagai suatu berkas dokumen mempunyai dua bentuk/jenis, yaitu rekam medis konvensional dan rekam medis elektronik. Rekam medis konvensional, seperti sudah disebutkan diawal, merupakan suatu tulisan/ catatan/dokumentasi yang secara kronologis dan sistematis menggambarkan dan menerangkan riwayat kesehatan penyakit seseorang.

Sedangkan definisi baku untuk rekam medis elektronik belumlah ada. Namun apabila melihat pengertian sistem elektronik dan informasi elektronik, maka rekam medis elektronik dapat didefinisikan sebagai suatu berkas dokumen elektronik yang berisikan riwayat perjalanan kesehatan seseorang. Dalam pelaksanaannya, seperti juga suatu sistem informasi elektronik lainnya, akan memerlukan suatu proses peng-input-an data dan untuk mengakses-nya kembali memerlukan suatu bentuk kode pengaksesan yang harus bersifat individual untuk menjamin kerahasiaan.

Jelas ada perbeadaan antara rekam medis konvensional dan rekam medis elektronik, sehingga kekuatan pembuktian dari keduanyapun akan berbeda. Di dalam Permenkes Nomor 269/MENKES/PER/III/2008 tentang Rekam Medis, memang telah disebutkan mengenai terdapatnya dua jenis rekam medis yaitu rekam medis konvensional dan rekam medis elektronik. Namun mengenai rekam medis elektronik ini, tidaklah diatur secara lengkap dan terperinci. Di dalam Pasal 2 ayat (2) Permenkes Nomor 269/MENKES/PER/III/2008 tentang Rekam Medis disebutkan bahwa penyelenggaraan rekam medis dengan menggunakan teknologi informasi elektronik akan diatur lebih lanjut dalam suatu peraturan tersendiri.

Peraturan tersendiri tersebut sampai saat ini belumlah ada. Padahal keperluannya sangatlah mendesak, hal ini didasari karena banyak rumah sakit (terutama di kota-kota besar di Indonesia) yang mulai menggunakan rekam medis elektronik (electronic medical record - eMR) karena perkembangan teknologi dan informasi serta tuntutan perbaikan mutu pelayanan kesehatan. Alasan lain untuk menggunakan rekam medis elektronik ini adalah pertimbangan business-marketing (contoh dengan menggunakan rekam medis elektronik juga membawa konsekuensi terhadap efisiensi tempat penyimpanan berkas serta menjadi ramah lingkungan [karena status paperless]).

Hal lain yang juga penting, yang mendasari pemikiran bahwa keperluan peraturan tersebut mendesak, adalah peran rekam medis sebagai suatu berkas alat bukti tertulis yang sah dalam pembuktian masalah-masalah hukum, etik dan disiplin. Peran fungsi ini dengan jelas disebutkan sebagai salah satu manfaat dari rekam medis dalam Permenkes Nomor 269/MENKES/PER/III/2008 tentang Rekam Medis.

Maka dari itu, suatu rekam medis, baik konvensional maupun elektronik, harus dipastikan dapat digunakan sebagai alat bukti tertulis yang sah. Dalam lalu lintas keperdataan, alat bukti tulisan merupakan salah satu dari lima alat bukti yang sah. Hal ini sesuai dengan Pasal 1866 Kitab Undang-Undang Hukum Perdata, dan alat bukti tulisan (berkas/surat) merupakan alat bukti yang utama.

Kemudian dalam ruang lingkup hukum pidana, surat juga merupakan salah satu dari lima alat bukti yang sah. Hal ini sesuai dengan apa yang tercantum di dalam Pasal 183 dan 184 Kitab Undang-Undang Hukum Acara Pidana, dalam pembuktian suatu perkara, dibutuhkan minimal 2 alat bukti yang sah, serta keyakinan hakim.

Hal ini sesuai dengan sistem pembuktian yang berlaku di Indonesia yaitu pembuktian menurut undang-undang secara negatif (negatief wettelijk stelsel). Di dalam sistem ini, seperti sudah disebutkan sebelumnya, kesalahan seseorang (terdakwa) ditentukan oleh adanya keyakinan hakim yang didasarkan kepada cara dan alat bukti yang ditentukan sesuai dengan undang-undang yang berlaku. 
Lebih lanjut, sudah disebutkan juga bahwa rekam medis harus dibubuhi identitas nama dari dokter, dokter gigi atau tenaga kesehatan tertentu yang mengisi berkas tersebut, waktu pengisiannya dan kemudian harus ditandatangani. Keaslian suatu alat bukti tulisan dapat menjadi masalah apabila tidak jelas payung hukumnya.

Sehubungan dengan hal ini, untuk rekam medis elektronik, akan memerlukan pedoman peraturan yang jelas mengenai penggunaannya. Tanda tangan elektronik, misalnya, yang meskipun sudah disebutkan definisinya dalam Undang-Undang Nomor 11 tahun 2008 tentang Informasi dan Transaksi Elektronik, namun masih menunggu pengaturan lebih lanjut, dalam bentuk Peraturan Pemerintah untuk pelaksanaannya.

Dengan mulai meningkatnya kasus-kasus dugaan malpraktik, yang tidak terselesaikan melalui proses mediasi, peran manfaat rekam medis sebagai salah satu alat bukti yang sah di pengadilan, makin dirasakan kebutuhannya. Rekam medis yang lengkap berisikan kronologis riwayat perjalanan kesehatan seorang pasien menjadi salah satu kunci penyelesaian kasus-kasus dugaan malpraktik.

Namun akan diperlukan suatu kejelasan, sesuai dengan asas kepastian hukum, akan penggunaan kedua jenis rekam medis ini, sebagai alat bukti yang sah. Kejelasan akan kekuatan pembuktian kedua jenis rekam medis ini, dapat diperoleh apabila terdapat suatu peraturan perundang-undangan yang mengaturnya.

Berdasarkan uraian di atas, timbullah pertanyaan: apakah ada perbedaan antara kekuatan pembuktian rekam medis konvensional dan rekam medis elektronik?

\section{PERMASALAHAN}

Dari latar belakang penelitian di atas, maka dirumuskan perumusan masalah penelitian yaitu: apakah ada perbedaan antara kekuatan pembuktian rekam medis konvensional dan rekam medis elektronik? Apa penyebab perbedaan kekuatan pembuktian antara rekam medis konvensional dan rekam medis elketronik?

Dalam rangka menjawab perumusan masalah penelitian ini, maka digunakan metode penelitian deskriptif dengan pendekatan yuridis normatif (doctrinal legal approach). Permasalahan pokok dalam penelitian ini, dikaji secara yuridis komparatif, dengan spesifikasi hukum normatif. Hal ini dilakukan untuk memperoleh gambaran tentang persamaan dan perbedaan kekuatan hukum pembuktian dari beberapa unsur-unsur dari rekam medis konvensional maupun rekam medis elektronik.

\section{PEMBAHASAN}

\section{Hukum Pembuktian}

Pembuktian merupakan titik sentral pemeriksaan perkara sidang pengadilan, dalam hal menngedepankan suatu kebenaran. Membuktikan meru-pakan suatu bagian dari proses hukum dimana diperlukan suatu proses untuk meyakinkan seorang hakim tentang suatu kebenaran dalil atau dalil-dalil yang dikemukakan dalam suatu persengketaan atau perselisihan. Seorang hakim mempunyai kewajiban untuk memeriksa dan menetapkan keabsahan dalil atau dalil-dalil yang diajukan kepadanya. ${ }^{1,2}$

Dalam melaksanakan proses tersebut, hakim harus mengindahkan aturan-aturan tentang pembuktian yang merupakan hukum pembuktian, bagian dari hukum acara. Hal ini semata-mata adalah untuk menjamin agar keadilan dapat ditegakkan sesuai asas kepastian hukum.

1 Lihat R. Subekti, 2010, Hukum Pembuktian, Pradnya Paramita, Jakarta, Cetakan 18, hlm. 1-5.

2 Lihat R. Subekti, 1989, Hukum Acara Perdata, Binacipta, Bandung, Cetakan 3, hlm. 78-81. 
Dalam Hukum Acara Pidana, ada empat teori sistem pembuktian, yaitu Conviction-in Time, Conviction-Raisonee, Pembuktian menurut Undang-Undang secara Positif (Positief Wettelijk Stelsel), dan Pembuktian menurut Undang-Undang secara Negatif (Negatief Wettelijk Stelsel). ${ }^{3}$ Sistem yang terakhir merupakan penggabungan teori antara sistem pembuktian menurut undang-undang secara positif dengan sistem pembuktian menurut keyakinan atau conviction-in time.

Berdasarkan apa yang tercantum dalam Pasal 183 Kitab Undang-Undang Hukum Acara Pidana, sistem pembuktian menurut undang-undang secara negatif (negatief wettelijk stelsel) inilah yang dianut di Indonesia. Dalam sistem ini, hakim baru boleh menjatuhkan pidana kepada seseorang apabila terdapat sekurang-kurangnya dua alat bukti yang sah dan ia memperoleh keyakinan bahwa suatu tindak pidana benar-benar terjadi dan bahwa terdakwalah yang melakukannya.

Alat-alat bukti yang sah adalah keterangan saksi, keterangan ahli, surat, petunjuk, dan keterangan terdakwa. Hal ini sesuai dengan apa yang tercantum dalam Pasal 184 Kitab Undang-Undang Hukum Acara Pidana. Meskipun alat bukti surat diurutkan ditengah-tengah, namun tetap saja mempunyai suatu nilai kepentingan.

Dalam hukum Acara Perdata, menurut Prof. Ali Afandi, terdapat tiga teori pembebanan pembuktian. Teori-teori tersebut adalah Teori Hak - Teori Hukum Subjektif; Teori Hukum Objektif; dan Teori Kepatutan. ${ }^{4}$ Teori kepatutan inilah yang paling sering digunakan karena dianggap sangat luwes. Dalam teori ini, seorang hakim harus mengadakan pembagian pembuktian berdasarkan keadilan, dimana beban pembuktian diberikan kepada pihak yang paling mudah dapat mengadakan pembuktian tersebut.

Alat-alat bukti yang sah, menurut Pasal 1866 Kitab Undang-Undang Hukum Perdata adalah: bukti tertulis, bukti dengan saksi-saksi, persangkaan-persangkaan, pengakuan, dan sumpah. Disini perbedaan yang paling jelas dibandingkan dengan hukum pidana adalah bahwa dalam lalulintas keperdataan, alat bukti yang utama adalah alat bukti tulisan (surat-surat), dan bukan kesaksian.

Terdapat dua macam alat bukti tulisan yaitu akta dan surat-surat lain. Akta dibagi lagi menjadi dua yaitu akta otentik dan akta di bawah tangan. Akta otentik mempunyai ketiga jenis kekuatan pembuktian ${ }^{5}$ yaitu kekuatan pembuktian eksternal, kekuatan pembuktian formal dan kekuatan pembuktian materiil. ${ }^{6}$ Hal ini sesuai dengan Kitab Undang-Undang Hukum Perdata. Dan dengan demikian akta otentik mempunyai kekuatan sempurna.

Akta di bawah tangan tidak mempunyai kekuatan pembuktian eksternal karena dibuat tanpa perantaraan seorang pejabat berwenang. Hal ini sesuai dengan Pasal 1874 Kitab Undang-Undang Hukum Perdata. Dan akta ini baru dapat dikatakan mempunyai kekuatan sempurna apabila akta tersebut telah diakui oleh para pihak yang bersangkutan.

Sedangkan surat-surat lain tidak diatur oleh Undang-Undang sehingga untuk kekuatan pembuktiannya, terserah kepada hakim. Hal ini sesuai dengan Pasal 1867 Kitab UndangUndang Hukum Perdata serta pendapat Prof. Eggens dan juga Van Vollenhoven. ${ }^{7}$

\footnotetext{
3 Lihat M. Yahya Harahap, 2008, Pembahasan Permasalahan Dan Penerapan Kitab Undang-Undang Hukum Acara Pidana, Sinar Grafika, Jakarta, Edisi 2, Cetakan 10, hlm. 276-279.

4 Lihat Ali Afandi, 1997, Hukum Waris, Hukum Keluarga, Hukum Pembuktian, Rineka Cipta, Jakarta, Cetakan 4, hlm. 196197.

5 Ibid, hlm. 199.

6 Lihat R. Subekti, Loc. Cit. 1, hlm. 25-30.

7 Lihat R. Soepomo, 2004, Hukum Acara Perdata Pengadilan Negeri, Pradnya Paramita, Jakarta, Cetakan 16, hlm. 82.
} 
Sebagai tambahan, harus diingat bahwa dalam hukum acara pidana, surat juga merupakan salah satu dari beberapa jenis alat bukti petunjuk yang sah. Hal ini sesuai dengan apa yang terdapat dalam Pasal 188 Kitab Undang-Undang Hukum Acara Pidana.

Unsur tanda tangan merupakan bagian penting dari suatu bukti tulisan atau surat. Karena dengan melakukan pembubuhan tanda tangan, harus diartikan bahwa para pihak menanggung kebenaran atau paling sedikit pengetahuannya tentang apa yang dituliskan di atas tanda tangannya tersebut. ${ }^{8}$

\section{Aspek Hukum Rekam Medis}

Rekam medis merupakan kumpulan segala kegiatan yang dilakukan oleh dokter, dokter gigi dan para tenaga kesehatan lainnya dalam memberikan pelayanan kesehatan yang berkesinambungan. Rekam medis menjadi salah satu kewajiban setiap dokter maupun dokter gigi, dalam melaksanakan praktik kedokterannya. Hal ini sesuai dengan Pasal 46 UndangUndang Nomor 29 Tahun 2004 tentang Praktik Kedokteran.

Sebagai pelaksanaan Pasal 47 Undang-Undang Nomor 29 Tahun 2004 tentang Praktik Kedokteran, ditetapkanlah Permenkes Nomor 269/MENKES/PER/III/2008 tentang Rekam Medis, sebagai pengganti peraturan sebelumnya, yaitu Peraturan Menteri Kesehatan Nomor 749a/Menkes/Per/XII/1989 tentang Rekam Medis.

Dalam Permenkes yang baru ini dengan jelas diatur mengenai kewajiban, jenis dan isi masing-masing rekam medis, tata cara penyelenggaraan rekam medis, kewajiban sarana pelayanan kesehatan, sifat rahasia rekam medis, dan berbagai manfaat dari rekam medis.

Namun untuk rekam medis elektronik, sesuai dengan Pasal 2 ayat (2) Permenkes ini, disebutkan bahwa akan diatur lebih lanjut dalam peraturan tersendiri. Hal ini belumlah ada sampai dengan saat ini. Padahal, rekam medis sebagai salah satu dari tiga Doktrin Hukum Kesehatan ${ }^{9}$, harus dipastikan kekuatan hukumnya yaitu sebagai salah satu unsur alat bukti tertulis yang sah dalam proses pengadilan, baik perdata maupun pidana.

\section{Rekam Medis Konvensional}

Rekam medis bukanlah suatu catatan ataupun rekaman dokumentasi semata. Rekam medis merupakan suatu berkas data yang berisikan antara lain identitas pasien, anamnesis, pemeriksaan fisik, diagnosis, dan segala tindakan yang telah dan akan dilakukan serta segala informasi administratif lainnya.

Penting sekali untuk selalu memperhatikan prinsip pelayanan berkesinambungan (continuity of care) dan selalu menjaga kejelasan dan kelengkapan dari suatu rekam medis. Semua pengaturan mengenai rekam medis konvensional adalah seperti yang tertuang di dalam Permenkes Nomor 269/MENKES/PER/III/2008 tentang Rekam Medis.

Kewajiban penulisan dengan jelas dan lengkap sudah disebutkan dalam Permenkes ini. Contoh kasus yang perlu diingat adalah kasus 'Larrimore vs Homeopathic Hospital Association of Delmore, 1962'. ${ }^{10}$ Kemudian mengenai pentingnya pembubuhan tanda tangan dan/atau paraf ini, Hayt dan Hayt dengan tegas menyebutkan bahwa tanda tangan seorang dokter yang merawat itu, sangatlah relevan jika kasus tersebut sampai di meja pengadilan. ${ }^{11}$

8 Op. Cit., hlm. 33.

9 Lihat Bambang Poernomo, Hukum Kesehatan, Penerbit Program Pendidikan Pascasarjana Fakultas Kedokteran Magister Manajemen Rumah Sakit Universitas Gadjah Mada, Yogyakarta, hlm. 111.

10 Lihat J Guwandi, 2010, Rahasia Medis, Balai Penerbit Fakultas Kedokteran Universitas Indonesia, Jakarta, Cetakan 2, hlm. 53.

11 Lihat Hayt, Emanuel and Hayt, Jonathan, 1964, Legal Aspect of Medical Record, Physician's Record Company, Illinois, hlm. 42-44. 
Kemudian dalam proses pembetulan suatu catatan. Disinipun tanda tangan dan/atau paraf sangatlah penting untuk dibubuhkan. Karena jika tidak dilakukan, dapat dianggap sebagai suatu tindakan perusakan alat bukti, dan dalam hal ini, alat bukti yang dimaksud adalah rekam medis. ${ }^{12}$ Dan H.L. Hirsch, seperti dikutip oleh Guwandi, mengatakan bahwa lebih baik seseorang dianggap telah melakukan kesalahan(error) dalam pencatatan daripada menghadapi tuduhan telah melakukan tindakan pemalsuan ataupun pemanipulasian (penipuan) dari suatu isi rekam medis. Jelaslah disini bahwa tindakan pembetulan yang dilakukan dengan benar, sangatlah penting. ${ }^{13}$

Kerahasiaan dan keamanan data rekam medis konvensional, merupakan unsure penting lainnya dari suatu rekam medis. Hal ini selain sudah disebutkan dalam Permenkes ini, juga telah disebutkan sebagai salah satu kewajiban rumah sakit dalam Pasal 29 ayat (1) poin $\mathrm{m}$ dan Pasal 32 poin i Undang-Undang Nomor 44 Tahun 2009 tentang Rumah Sakit.

Sedangkan mengenai manfaat rekam medis, juga secara jelas telah tertuang dalam Pasal 13 ayat (1) Permenkes ini. Rekam medis konvensional ini, disisi lain mempunyai beberapa kelemahan. Yang pertama adalah berhubungan dengan manajemen dan penyimpanan rekam medis, dimana membutuhkan ruang, waktu dan biaya yang terus bertambah.

Kelemahan kedua berhubungan dengan tidak dapat terbacanya tulisan seorang dokter atau dokter gigi. Hal ini selain mengakibatkan dapat terjadinya ketidakefisiensian pelayanan kesehatan, juga dapat mengakibatkan suatu kejadian yang fatal, yaitu sebagai contoh dapat terjadinya suatu kesalahan pemberian jenis ataupun dosis obat.

\section{Rekam Medis Elektronik}

Apabila mempertimbangkan Pasal 1 poin 1, 3 dan 5 Undang-Undang Nomor 11 Tahun 2008 tentang Informasi dan Transaksi Elektronik, maka rekam medis elektronik dapat didefinisikan sebagai suatu pencatatan Informasi Elektronik yang dibuat, diteruskan, dikirimkan, diterima, atau disimpan dalam berbagai bentuk, melalui suatu Sistem Elektronik, termasuk omputer, yang berisi semua data/informasi pasien. Hal ini menggunakan Teknologi Informasi.

Meskipun secara spesifik belum ada peraturan mengenai rekam medis elektronik, namun secara umum kewajiban penulisan, tanda tangan dan penjagaan kerahasiaan data tetaplah berlaku. Autentikasi siapa yang memasukkan data harus dengan jelas dan cepat dapat diidentifikasi. Hal ini harus juga sesuai dengan apa yang telah disebutkan dalam Joint Commission International $(\mathrm{JCl}){ }^{14,15}$ sebagai salah satu badan akreditasi rumah sakit internasional dan Electronic Code of Federal Regulations (e-CFR) BETA TEST SITE.

Mengenai tanda tangan elektronik, pengaturannya, sesuai dengan Pasal 11 ayat (2) Undang-Undang Nomor 11 Tahun 2008 tentang Informasi dan Transaksi Elektronik, akan diatur kemudian. Hal ini belumlah ada.

Pemanfaatan perkembangan teknologi informasi pada umumnya berperan penting dalam perdagangan dan pertumbuhan perekonomian. Begitu pula dengan adanya suatu sistem rekam medis elektronik, diharapkan dapat lebih banyak memberikan manfaat. Selain manfaat rekam medis secara umum dan pemanfaatan teknologi informasi dan elektronik

12 Lihat Marguerite Barbacci, et. al., 2004, Medical Errors and Litigation: Investigation and Case Preparation, Lawyers and Judges Publishing Company, Inc., Tucson, hlm. 266.

13 Lihat J. Guwandi, 2009, Pengantar Ilmu Hukum Medik Dan Bio-etika, Balai Penerbit Fakultas Kedokteran Universitas Indonesia, Jakarta, hlm. 61.

14 Joint Commission International, 2010, Joint Commission International Accreditation Standards For Hospitals, Department of Publications Joint Commission Resources, USA, hlm.241-243.

15 Ibid., hlm.235-239. 
(sesuai dengan Pasal 4 Undang-Undang ini), terdapat beberapa manfaat lain, diantaranya sifat 'paperless' dari sistem elektronik ini yang berakibat pada lebih ramah lingkungan.

Salah satu kelemahan dari sistem ini, adalah harganya yang mahal sehingga tidak semua rumah sakit dapat memanfaatkan kelebihan dari sistem ini. Kelemahan lain yang sangat penting adalah sulitnya menjaga keamanan dan kerahasiaan data terutama apabila terjadi kerusakan sistem atau 'breakdown'.

\section{Perbedaan Kekuatan Pembuktian Rekam Medis Konvensional Dan Elektronik}

Rekam medis konvensional maksimal dapat dikategorikan sebagai akta di bawah tangan. Akta demikian hanya mempunyai dua jenis kekuatan pembuktian, yaitu kekuatan pembuktian formal dan materiil.

Tabel 1. Perbedaan Kekuatan Pembuktian Kedua Jenis Rekam Medis

\begin{tabular}{|l|l|l|}
\hline & \multicolumn{1}{|c|}{$\begin{array}{c}\text { REKAM MEDIS } \\
\text { KONVENSIONAL }\end{array}$} & \multicolumn{1}{c|}{$\begin{array}{c}\text { REKAM MEDIS } \\
\text { ELEKTRONIK }\end{array}$} \\
\hline ALAT BUKTI TERTULIS & $\begin{array}{l}\text { Sah, sesuai dengan } \\
\text { Permenkes tentang } \\
\text { Rekam Medis }\end{array}$ & $\begin{array}{l}\text { Bukan merupakan alat } \\
\text { bukti yang sah, } \\
\text { berdasarkan syarat- } \\
\text { syarat alat bukti tertulis } \\
\text { atau surat }\end{array}$ \\
\hline $\begin{array}{l}\text { KEKUATAN PEMBUKTIAN } \\
\text { EKSTERNAL }\end{array}$ & Tidak ada & Tidak ada \\
\hline $\begin{array}{l}\text { KEKUATAN PEMBUKTIAN } \\
\text { FORMAL }\end{array}$ & $\begin{array}{l}\text { Ada, asalkan diakui oleh } \\
\text { para pihak }\end{array}$ & Tidak ada \\
\hline $\begin{array}{l}\text { KEKUATAN PEMBUKTIAN } \\
\text { MATERIIL }\end{array}$ & $\begin{array}{l}\text { Ada, asalkan diakui oleh } \\
\text { para pihak }\end{array}$ & Tidak ada \\
\hline $\begin{array}{l}\text { BENTUK } \\
\text { AKTA }\end{array}$ & Akta di bawah tangan & $\begin{array}{l}\text { Tidak berbentuk tulisan } \\
\text { asli }\end{array}$ \\
\hline
\end{tabular}

* Permenkes Nomor 269/MENKES/PER/III/2008 Tentang Rekam Medis

** Berdasarkan Pasal-Pasal 184 ayat (1) huruf c,d, 187 dan 188 ayat (2) huruf b Kitab UndangUndang Hukum Acara Pidana

$\S$ Dengan demikian tidak dapat dipakai sebagai alat bukti yang kuat di pengadilan (prima facie proof)

Sedangkan rekam medis elektronik, dikarenakan tidak berbentuk tulisan asli, termasuk berkaitan dengan keaslian pembubuhan identitas nama, waktu dan tanda tangan elektronik, maka rekam medis ini tidak dapat dikategorikan ke dalam bentuk alat bukti tertulis atau surat. Dengan demikian, rekam medis elektronik tidak mempunyai kekuatan pembuktian eksternal, formal maupun materiil. Perbandingan perbedaan kekuatan pembuktian dari masing-masing jenis rekam medis, dapat dilihat dalam Tabel 1.

\section{Penyebab Perbedaan Antara Rekam Medis Konvensional Dan Elektronik}

Tabel 2., berikut ini, menunjukkan perbandingan beberapa unsur-unsur dari kedua jenis rekam medis, yang berkaitan dengan kekuatan hukum pembuktian.

Apabila dilihat dari Tabel 1. dan juga Tabel 2., terdapat beberapa hal yang menyebabkan perbedaan diantara kedua jenis rekam medis ini. Dilihat dari hukum kekuatan pembuktian, rekam medis elektronik bukan merupakan alat bukti tertulis atau surat yang sah. 
Rekam medis elektronik, baik dalam penulisan/ pendokumentasian, maupun pembubuhan identitas nama, waktu dan tanda tangan serta pembubuhan paraf untuk pembetulan, semuanya itu tidak dalam konteks tulisan asli. Hal ini menyebabkan rekam medis elektronik tidak memenuhi syarat sebagai alat bukti tertulis atau surat.

Jadi perbedaan kekuatan pembuktian di antara kedua rekam medis ini terletak pada tidak terpenuhinya syarat rekam medis elektronik sebagai alat bukti tertulis atau surat. Hal ini sesuai dengan Kitab Undang-Undang Hukum Perdata Buku 4, tentang Pembuktian dan Daluarsa, Bab Kedua tentang Pembuktian dengan Tulisan dan Kitab Undang-Undang Hukum Acara Pidana Pasal 184 ayat (1) huruf c dan d, serta Pasal-Pasal 187 dan 188 ayat (2) huruf b.

Tabel 2. Perbedaan Unsur-Unsur Dari Kedua Jenis Rekam Medis

\begin{tabular}{|c|c|c|}
\hline & $\begin{array}{l}\text { REKAM MEDIS } \\
\text { KONVENSIONAL }\end{array}$ & $\begin{array}{l}\text { REKAM MEDIS } \\
\text { ELEKTRONIK }^{*}\end{array}$ \\
\hline $\begin{array}{l}\text { PENULISAN/PENCATATAN/ } \\
\text { PENDOKUMENTASIAN }\end{array}$ & $\begin{array}{l}\text { Wajib dilakukan dan } \\
\text { harus dibuat dengan } \\
\text { lengkap serta jelas, } \\
\text { tergantung pada tulisan } \\
\text { tangan }\end{array}$ & $\begin{array}{l}\text { Wajib dilakukan } \\
\text { Tulisan terbaca dengan } \\
\text { lebih jelas }\end{array}$ \\
\hline $\begin{array}{l}\text { PEMBUBUHAN IDENTITAS } \\
\text { NAMA, WAKTU DAN TANDA } \\
\text { TANGAN }\end{array}$ & $\begin{array}{l}\text { Wajib dilakukan secara } \\
\text { manual }\end{array}$ & $\begin{array}{l}\text { Tetap wajib dilakukan; } \\
\text { nama identitas dan } \\
\text { waktu dapat secara } \\
\text { otomatis ter-entry, } \\
\text { tergantung Sistem } \\
\text { Elektronik yang } \\
\text { digunakan, namun untuk } \\
\text { tanda tangan elektronik } \\
\text { belum jelas }\end{array}$ \\
\hline $\begin{array}{l}\text { PEMBUBUHAN PARAF } \\
\text { UNTUK PEMBETULAN }\end{array}$ & $\begin{array}{lr}\text { Harus sesuai } & \text { dengan } \\
\text { perundangan } & \text { yang } \\
\text { berlaku dan dilakukan } & \\
\text { secara manual } & \end{array}$ & Belum jelas \\
\hline $\begin{array}{ll}\text { KERAHASIAN } & \text { DAN } \\
\text { KEAMANAN DATA } & \end{array}$ & $\begin{array}{l}\text { Harus sesuai dengan } \\
\text { Undang-Undang Praktik } \\
\text { Kedokteran, Undang- } \\
\text { Undang Rumah Sakit }{ }^{* *} \\
\text { dan Permenkes tentang } \\
\text { Rekam Medis }{ }^{\S}\end{array}$ & $\begin{array}{lr}\text { Harus sesuai } & \text { dengan } \\
\text { perundangan } & \text { rekam } \\
\text { medis secara } & \text { umum, } \\
\text { namun secara elektronik } \\
\text { bergantung pada } & \text { Sistem } \\
\text { Elektronik r yang } & \text { digunakan }\end{array}$ \\
\hline MANFAAT & \begin{tabular}{|lr} 
Sesuai & dengan \\
Permenkes & tentang \\
Rekam Medis & \\
\end{tabular} & $\begin{array}{l}\text { Selain manfaat rekam } \\
\text { medis pada umumnya, } \\
\text { juga memiliki manfaat- } \\
\text { manfaat lain seperti } \\
\text { ramah lingkungan } \\
\text { (karena status paperless- } \\
\text { nya), lebih efektif dan } \\
\text { efisien serta mendorong } \\
\text { sinergisme pelayanan }\end{array}$ \\
\hline
\end{tabular}




\begin{tabular}{|l|l|l|}
\hline KELEMAHAN & Tidak ramah lingkungan & Kerahasiaan data tidak \\
Memerlukan sistem & dapat dijaga apabila \\
manajemen dan & sistem kena virus atau \\
penyimpanan yang baik & 'breakdown' \\
serta memerlukan ruang & Harga yang mahal \\
untuk penyimpanan & \\
Kejelasan penulisan & \\
sangatrrang tergantung & \\
penulisnya & \\
\hline
\end{tabular}

* Perhatikan bahwa sampai dengan saat ini belum ada peraturan perundang-undangan yang mengatur rekam medis elektronik

** Undang-Undang Nomor 29 Tahun 2004 tentang Praktik Kedokteran dan UndangUndang Nomor 44 Tahun 2009 tentang Rumah Sakit

$\S$ Permenkes Nomor 269/MENKES/PER/III/2008 Tentang Rekam Medis

$\S \S$ Perlu diperhatikan Electronic Code of Federal Regulations (e-CFR) BETA TEST SITE dan Joint Commission International

Dengan demikian, rekam medis konvensional dapat digunakan sebagai alat bukti asli tertulis, sedangkan rekam medis elektronik tidak memiliki kekuatan pembuktian sama sekali (seperti ditunjukkan di Tabel 1.) dan tidak memenuhi syarat yang digunakan sebagai alat bukti tertulis. Dan penyebab perbedaan ini adalah tidak adanya pengakuan, baik dalam Kitab Undang-Undang Hukum Perdata maupun Kitab Undang-Undang Hukum Acara Pidana, tentang alat bukti elektronik dan masih tetapnya alat bukti tulisan dalam bentuk tulisan, berupa surat asli dan/atau akta otentik.

Kemudian mengenai perbedaan-perbedaan lain, yang tidak berhubungan dengan kekuatan pembuktian adalah seperti yang tertera dalam Tabel 2. Perbedaan-perbedaan ini berhubungan dengan beberapa unsur dari rekam medis elektronik, seperti penulisan/pendokumentasian, pembubuhan identitas nama, waktu dan tanda tangan (termasuk paraf dalam pembetulan), kerahasian dan keamanan data serta pemanfaatan rekam emdis elektronik. Perbedaan-perbedaan unsur rekam medis ini disebabkan adanya ketidakjelasan perundang-undangan yang mengatur rekam medis elektronik secara khusus dan juga peraturan perundang-undangan yang mengatur tanda tangan elektronik.

\section{PENUTUP}

Dengan demikian penggunaan rekam medis elektronik, yang semestinya merupakan salah satu alat bukti tertulis atau surat yang sah dalam suatu perkara medis di persidangan, menjadi tidak sah karena tidak memenuhi elemen kekuatan pembuktiannya. Hal ini disebabkan karena rekam medis elektronik bukan berbentuk surat/tulisan asli, begitu pula dengan unsur identitas nama, waktu dan tanda tangan (termasuk paraf untuk pembetulan).

Tidak adanya kejelasan mengenai rekam medis elektronik, dalam bentuk suatu peraturan perundang-undangan, berakibat pada ketidakjelasan penggunaan/ pemanfaatan rekam medis itu sendiri. Namun hal ini bukan sebagai penyebab perbedaan kekuatan pembuktian diantara kedua jenis rekam medis ini.

Secara umum, kedepannya diharapkan bahwa peraturan mengenai rekam medis elektronik, selain berisikan unsur-unsur rekam medis pada umumnya, sesuai dengan Permenkes Nomor 269/MENKES/PER/III/2008 Tentang Rekam Medis, seyogyanya juga mempertimbangkan beberapa hal yang khusus berhubungan dengan sistem informasi elektronik dan juga dengan 
seksama, mempertimbangkan aspek kekuatan pembuktiannya. Hal ini harus juga dipastikan agar sesinkron mungkin dengan Undang-Undang yang berlaku di atasnya, sesuai dengan hierarki perundang-undangan.

\section{DAFTAR PUSTAKA}

\section{Literatur}

Ali Afandi, 1997, Hukum Waris, Hukum Keluarga, Hukum Pembuktian, Rineka Cipta, Jakarta, Cetakan 4.

Bambang Poernomo, Hukum Kesehatan, Penerbit Program Pendidikan Pascasarjana Fakultas Kedokteran Magister Manajemen Rumah Sakit Universitas Gadjah Mada, Yogyakarta.

Hayt, Emanuel and Hayt, Jonathan, 1964, Legal Aspect of Medical Record, Physician's Record Company, Illinois, USA.

J. Guwandi, 2010, Rahasia Medis, Balai Penerbit Fakultas Kedokteran Universitas Indonesia, Jakarta, Cetakan 2.

--------, 2009, Pengantar Ilmu Hukum Medik Dan Bio-etika, Balai Penerbit Fakultas Kedokteran Universitas Indonesia, Jakarta, hlm. 61.

Joint Commission International, 2010, Joint Commission International Accreditation Standards For Hospitals, Depatment of Publications Joint Commission Resources, USA.

Marguerite Barbacci, et. al., 2004, Medical Errors and Litigation: Investigation and Case Preparation, Lawyers and Judges Publishing Company, Inc., Tucson, USA.

M. Yahya Harahap, 2008, Pembahasan Permasalahan Dan Penerapan KUHAP, Sinar Grafika, Jakarta, Edisi 2, Cetakan 10.

R. Soepomo, 2004, Hukum Acara Perdata Pengadilan Negeri, Pradya Paramita, Jakarta, Cetakan 16.

R. Subekti, 2010, Hukum Pembuktian, PT Pradnya Paramita, Jakarta, Cetakan 18.

-------, 1989, Hukum Acara Perdata, Percetakan Binacipta, Bandung, Cetakan 3.

\section{Peraturan Perundang-Undangan}

Undang Undang Dasar Republik Indonesia Tahun 1945

Kitab Undang-Undang Hukum Acara Pidana

Kitab Undang-Undang Hukum Perdata

Undang-Undang Republik Indonesia Nomor 29 Tahun 2004 tentang Praktik Kedokteran

Undang-Undang Republik Indonesia Nomor 11 Tahun 2008 tentang Informasi dan Transaksi Elektronik

Undang-Undang Republik Indonesia Nomor 44 Tahun 2009 tentang Rumah Sakit

Peraturan Menteri Kesehatan Republik Indonesia Nomor 269 Tahun 2008 Tentang Rekam Medis 